\title{
Inclusive Practices as Empowering Venture for Persons with Disabilities: The Case of ST Angela Vocational School for the Deaf in Mumias, Kenya
}

\author{
Bota $^{1} \quad$ Sichari M. ${ }^{1} \quad$ Ilolanga L. ${ }^{2}$ \\ 1.Masinde Muliro University of Science and Technology \\ 2. St Angela Vocational Secondary School for the Deaf Mumias
}

\begin{abstract}
In Kenya, a disproportionate number of persons with special needs and disabilities are unable to access quality education and training. However, this is being reduced by the practice of inclusive education as outlined by the 2018 Inclusive Education Policy. The paper focuses on three persons with disabilities who have been empowered through inclusive practices in Education. They are: Benta, Julia and Agnes (not their real names). These people are self-employed and successful interacting with their non-disabled customers who acknowledge their contribution to the society. The paper established that inclusive practices enhances positive attitude among stakeholders. It also increases self-esteem and confidence. Furthermore, it creates a situation for comparison among stakeholders, hence empowering persons with disabilities
\end{abstract}

Keywords: Inclusive practices, Empowering, Persons with disabilities, Non-disabled persons, attitude, equal opportunities.

DOI: $10.7176 / \mathrm{JEP} / 11-9-05$

Publication date:March $31^{\text {st }} 2020$

\section{Background}

It is worth noting that empowerment of people with disabilities, especially in socio-economic issues as well as decision making on matters affecting them either directly or indirectly is crucial in ensuring that they enjoy equal opportunities in society. According to Giangreco et al (2010), disability should be recognized as a form of human diversity. In this regard, students with disabilities need to be accepted as individuals and not denied access to educational opportunities based on disability. In Kenya, such emphasis is captured in Article 10 (2) of the Constitution which stipulates the national values and principles of governance as social justice, human dignity, equity, inclusiveness, equality, human rights, non-discrimination and protection of the marginalized should be underscored as the government recognizes the importance of special needs education as an important subsector for accelerating the attainment of the Kenya Vision 2030, the governments Big Four Agenda and Sustainable Development Goals.

In recognition of the intrinsic human value of education, underpinned by strong moral and legal foundations, the government signed Article 26 of the Universal Declaration of Human Rights of 1948, thereby committing itself to the right of every person to access education. Other international policy frameworks ratified and signed by the government include the United Nations Convention on the Rights of the Child of 1989, the African Charter on the Rights and Welfare of the Child of 1990, the World Conference on Special Needs (Salamanca Statement) of 1994, the Framework for Action on Special Needs Education of 1999 and the United Nations Convention on the Rights of Persons with Disability (UNCRPWD, 2006). It is worth noting that by virtue of Article 2 (6) of the Constitution, treaties or conventions ratified by Kenya form part of its laws.

Educational opportunities for learners with special needs and disabilities are a major challenge to the education sector. Therefore, there is need, to remove barriers within the education system that bar them from inclusiveness as well as equity. Rule number six (6) of the United Nations Standard Rules on the Equalization of Opportunities, not only reiterates the rights of people with disabilities to education, but also states that education should be offered in integrated as well as general school settings (UNESCO, 1994). Additionally, the UNCRPWD (2006) affirms the right to education in an inclusive setting for all children, with the emphasis being to enable children with special needs to enroll in schools of their choice within their localities.

\section{Empowerment theory}

This paper is guided by the empowerment theory which is commonly used in research as a means to predict and explain the behavior of an individual or group within social constraints as well as amount of power in decision outcomes. It is based on the assumption that an individual or group of individuals gains a voice in decisions that affect them as well as the social structure that either encourages or discourages it. Accordingly, the theory can be applied to individuals, communities, organizations and social policies. Hallahan \& Kauffman, (2012) notes that empowerment has become a vital construct for understanding the development of individuals, organizations and communities. The researchers argue that empowerment is more than the traditional psychological constructs with 
which it is sometimes compared or confused like self-esteem, self-efficacy, competency and locus of control. While outcomes in organizations might include development of organizational networks, growth and leverage, community level empowerment outcomes might include evidence of pluralism, existence of organizational coalitions and accessibility to community resources. This was realized in the case of Benta dressmaking skills. This paper intends to sensitize the Kenyan population and the achievements of people with special needs who have gone through inclusive practices at school, community and working levels. It also highlights the importance of teachers as integral parts in giving solutions to inclusive practices. And that to minimize non-acceptance practices from both disabled and non-disabled, the way forward is inclusive environment of the disabled and non-disabled.

\section{Inclusive Practices}

According to Giangreco et al (2010), implementing inclusive education at the classroom level requires thoughtful attention to four interrelated components, namely: inclusive environments, individualized curriculum, purposeful instruction and necessary supports. Within this framework, students with disabilities gain access by virtue of their status as children and youth who are eligible for schooling (Giangreco et al). Deng (2010) argues that the unique instructional needs of many students with disabilities pose a big challenge to the ingenuity of general education teachers. Particularly, teachers who successfully include students with disabilities have to constantly make decisions about what will be adapted in their curriculum as well as instruction. Accordingly, the movement towards an inclusive curriculum requires modifications to the existing curriculum as well as the teaching methods and practices used to implement it. Curricular adaptations are modifications that relate specifically to instruction or curriculum content in general classrooms meant to enhance a person's performance or allow at least partial participation in an activity.

Giangreco et al (2010) asserts that teachers who successfully include students with disabilities in their classes demonstrate ownership for the students' education by becoming instructionally engaged. Among others, this means that such teachers are knowledgeable about the students' performance levels and individualized learning outcomes; spend time directly providing instruction to the student with disability; retain a prominent role in instructional planning and decision making with special education personnel; mentor and co-direct the work of any teacher assistants who are present in the classroom; and advance their own learning to improve their inclusive skills. The researchers assert that it may be helpful to remind teachers that their fundamental skills are well suited to educating students with disabilities and that collaboration is essential among all team members. Accordingly, having school personnel, students and families collaboratively working together with a shared vision toward common goals is clearly a foundation for success. This is confirmed by the following case studies.

\section{Collaborative training in inclusive practice}

According to Metto and Makewa, (2014) team approaches have become increasingly popular for addressing diversity in schools and collaborative teaching is aimed at improving services to students whose needs are not being met satisfactorily when professionals act alone rather than in consultation with others; or working collaboratively, Deng (2010) observes that many advocates of inclusive education urge the educators to communicate regularly with each other. A series of the so called best practice-related collaborations have been widely recommended to teachers working in inclusive settings. They include, cooperative learning, curricular adaptations, students supporting students, using paraprofessional/classroom aids and using instructional technology. Therefore successful collaboration includes cooperative learning as well as collaborative consultation.

Thus successful collaboration includes cooperative learning as well as collaborative consultation. In their study in collaboration teaching in vocational centers for the deaf, Mabele and Bota (2016) underscored the strategy. Through it Julia made it as observed in case study 2

\section{Parents in transformative teaching approach}

Parents are an integral part of teaching, their contribution in transformative teaching cannot be gainsaid. Parents of children with disabilities need to accept the reality of the situation. Living in denial is detrimental to both learner and the parent. Extreme reactions such as being over-protective or active aggression may cause emotional and psychological trauma to the child with disability. Parents are better placed to diagnose disability problems from an early age and therefore institute early intervention with the assistance of teachers. Gardner 1996 portrays the learner with disability as "a puzzled child, a frustrated child and too often, a defeated child". To mitigate the psychosocial problems such as low self-esteem associated with disabilities parents ought to assume the role of a coach and interpreter to assist the child unravel the puzzles of the social and academic world and train the child using learner friendly techniques to master skills and knowledge that the learner presumes is beyond their ability.

\section{Transformative Inclusion}

Transformative teaching should target making the schooling experience valuable for the present and future. It is 
not only about retaining the learners in school by providing a psychologically healthy environment cognizance of the fact that the impact may be life-long. Schooling should create respect and concern for oneself and others and enhance an individual's character. Woolfson, (2007) has further noted that it is about developing a sense of cooperation and working with others and genuine concern for self and others which is an anticipated benefit of cooperative teaching. Through this approach, Agnes managed to acquire dress making skills that have transformed her life.

\section{Case study 1: Benta (Dressmaking)}

Benta joined St. Angela Vocational school in the year 1996 at 21 years. She came from Maseno School for the deaf. This is a school that offers education to learners with hearing impairment. This type of learners may be totally deaf or with mild hearing which is called hard-of hearing. Benta is totally deaf and while in this school she had learnt the basic skills in knitting, typing and dressmaking among others. She learnt in the vocational school for four years. The first year of her vocational education, she was introduced to dressmaking, knitting, type-writing, office practice, art and craft among others and she did well in the introductory work. She showed a lot of interest and also enjoyed dressmaking. In her second year measurement, pattern cutting and theory of dressmaking was a big challenge to her. This was noticed by the teacher and it almost made her give up. Fortunately, she joined st. Angela vocational school when she had mastered Kenyan Sign language (KSL) and this made it possible for the teacher to use KSL to explain concepts in dressmaking and communicate well with her. KSL is a language that has common signs and is used in Kenya by the deaf community. KSL may not be the same as any other country's sign language. The sign language used in Kenya only has variations whereby people from a certain region may sign an item differently from people of another region.

As she finished school she graduated with dressmaking grade II. She also managed to get an internal certificate in dressmaking which was given during graduation. In dressmaking the students start with grade III in form two and finish with grade II at form four levels. She managed to secure a job of dressmaking in Maseno School for the deaf. She was in charge of school uniforms. That means she was to make the uniforms to be worn by all the pupils in the school. Her salary was Ksh $6,000 /=$ per month. Later the school had sponsors who sponsored the school shop where Benta was transferred to work. Her transfer was along with salary increment to Ksh 12,000/=. Another challenge Benta encountered was lack of a sewing machine. She intended to purchase a sewing machine. Since Benta was working she made a saving from her salary and bought a sewing machine on a loan worthy Ksh 28,000 . She went ahead and employed one person to use the machine for a start as she continued working. Benta's family provided premises for her and together with the help of the husband who was an electrician; she was able to purchase two more machines and employed two more people. Benta continued experiencing challenges in the community as she left Maseno to settle for full-time self-employment in Lwanda market. Members of her community did not accept her and they were not convinced that she could do a good job of the production of a garment. Lucky enough Benta had employed hearing people and so they actually did marketing of her skill in the community. They could literally bring customers from the community. The moment they made a well neat finished garment under Benta's instructions it was enough to bring people closer. They firmly accepted her as one of the best dressmakers in Lwanda market in Bunyore. Benta's father passed on leaving behind their mother and many siblings. At one point Benta had to pay school fee for her brother in secondary school when she was working. This case demonstrates that skills and knowledge acquired in an inclusive setting not only prepare students in an inclusive world of work environment, but also makes them fully self reliant and employment creators.

\section{Case study 2: Julia (knitting)}

Julia came from Kilimani primary school, a deaf-blind unit in Nairobi. She was a student with multiple impairment, i.e., visual and hearing impairment. People with these two sensory impairments are termed as deaf-blind. Julia was deaf-blind though she had some slight vision which enabled her to use KSL. Kilimani primary school is a school for regular students with a section that admits learners with both vision and hearing problems. While in Kilimani primary, she learnt the basics in knitting, beadwork and crocheting among others. She was admitted to St. Angela vocational school in the year 2009 at the age of 19 years. When she joined the St. Angela vocational school she was introduced to knitting, beadwork, crocheting, laundry, cookery, and frame weaving. Out of these skills taught Julia was able to grasp skills in knitting faster.

After graduation Julia had a challenge of acquiring a knitting machine. She overcame this challenge when an NGO called Sense International E.A provided a start-up kit for her. A planning committee which was formed prepared for her a transitional training program. It also looked at her potential and the strong vocational skills of she had and decided to buy her material to use for knitting. Knitting was her area of strength. She enriched her skills through practice and these days she is an instructor at Kilimani inclusion programme in Nairobi.

\section{Case study 3: Agnes (Dressmaking)}

Agnes was admitted to St. Angela Vocational school in Mumias in 1998 at 17 years of age. She came from Maseno 
primary school for the deaf. This is a school that admits learners with hearing impairment. Agnes is a student who is deaf. While in primary school she was introduced to basic skills in dressmaking, knitting, art and craft. In St. Angela vocational school, Agnes continued learning skills in dressmaking, knitting, type-writing, and office practice. Agnes showed better grasp in dressmaking skills and this was also encouraged by her teachers. On joining vocational school, Agnes had mastered KSL. The teacher taught her the skills through practical work. Agnes experienced challenges in dressmaking theory since she did not have a good background in language development. The teacher had to incorporate other teachers in Agnes's' learning process and a strategy commonly referred to as team teaching. One of the teachers incorporated was the English teacher who taught English as a support subject. The dressmaking teacher had to collaborate with the English teacher in the vocabulary needed in dressmaking. She also incorporated the mathematics teacher who assisted her on measurements and drawing, and basic operations.

As she came back for the dressmaking lesson she had to use that knowledge to measure, draw and cut patterns. The mathematics and English teachers used KSL as support subjects to the learning of dressmaking. Agnes learnt this for six years to be able to produce a neat garment. In evaluation the teacher assessed the sections of the garment and awarded marks. The final garment was also assessed and marks awarded. Apart from that she managed to do Government Trade Test by the National Industrial Training Authority (NITA) and secured a dressmaking certificate in Grade III in form two and Grade II in form three. After finishing her form four level of education, she had managed to get Grade I certificate.

After graduation she did industrial attachment where she practiced in the production of sales, marketing of products and record keeping. At the same time she faced a challenge of how to start a job since she did not have capital. She decided to work under another person's business first. The other challenge in the community was acceptance. Though she had dressmaking skills she felt she would not be accepted in the community and she may not fair on well with dressmaking. The person she worked under assisted in marketing her and she was able to penetrate the market.

The idea she had of micro-business was developed by teachers during the learning process where entrepreneurship education and skill training was part of the curriculum. This education gave her ideas on how to run business. Industrial attachment and enterprise farms also exposed her and she interacted well with her clients and got business ideas. Communication barrier was another challenge she faced in the community. This barrier could sometimes make her not to be understood or be mistaken. To avoid this she could sometimes look for an interpreter or write on paper where she also gave answers through written messages. Currently Agnes is working in a dressmaking shop in Mumias where she earns between Ksh 4,000/= and Ksh 18,000/= per month. This means she earns more when they have made more sales and earns less when they have less sales. She is able to operate an account and she is saving to buy her own sewing machine and start her own business. She stays alone but she is anticipating to get married.

\section{Discussion}

Inclusive practices are key to reduced stress, depression and general mental health of the people living with disabilities. Giangreco, et-al (2010), suggests that disability should be recognized as a form of human diversity. Therefore, students and persons with disabilities need to be accepted as individuals who are capable of living and working towards achieving their goals if given appropriate training. As the cases of Benta, Julia, and Agnes.

They went through inclusive arrangement at primary, secondary, and vocational training and now in their adulthood they are in stress free situation and environment that is full of love ingredients from them, families, the local community and their practices (entrepreneurship). This positive lifestyle is attributed to their teachers' fellow students, families and society who put into practice good inclusive teaching strategies, (Mabele \& Bota, 2016).

\section{Conclusion}

From the studies reviewed, this paper concludes that:

1. Inclusive practices enhances positive correlation with the attitude of all the stakeholders i.e. the society, the community, the tutors, the teachers, those with disabilities and those without disabilities.

2. Experience of inclusive practices predisposes individuals' disabilities to lifestyle needs and capabilities hence reducing self-doubt, and increasing self-esteem and self-confidence.

3. Inclusive practice networks do develop positive feelings in a an individual with disabilities and enhance social comparison, especially when one sees manifestations of others living a better life. If those with disabilities are to benefit from inclusive practices, it is important that they understand and manage their relationship with the non-disabled, the community and the entire environment with feeling that they are valuable members of the larger society.

\section{References}

Deng, M (2010). Developing Inclusive Approaches to Teaching and Learning. In Rose, R (ed.).Confronting Obstacles to Inclusion: International Responses to Developing Inclusive Education (pp. 203-212). London: 
Routledge.

Gardener , B.V. (1996) . Using teacher development to foster inclusive classroom practice. Developing Teacher Education .London: Routledge

Giangreco, M. F., Carter, W. E., Doyle, B.M \&Suter, C. J (2010). Supporting Students with Disabilities in Inclusive Classrooms: Personnel and Peers.In Rose, $\mathrm{R}$ (ed.). Confronting Obstacles to Inclusion: International Responses to Developing Inclusive Education (pp. 247-263). London: Routledge.

Hallahan, P. D., Kauffman, M. J., \& Pullen, C. P. (2012). Exceptional Learners: An Introductionto Special Education. Boston, MA: Pearson.

Kenya constitution, (2010). Constitution Of Kenya; Nairobi: Government Printer

Mabele, E. \& Bota K.N. (2016). Inclusive education for lifelong learning and transitions in the world of work in Kenya. Lessons from St. Angela Mumias secondary \& vocational school. Kenyan journal of guidance, councelling and psychology, vol. 6 No. 1 pp 26 - 32; ISSN $2226-0552$.

Metto, E., \& Makewa, N. L. (2014). "Learner-centered Teaching: Can It work In Kenya Public Primary Schools". American Journal of Educational Research, 2-11A, 23-29. doi: 10.12691/education

UNESCO, (1994).United Nations Educational Science and Cultural Organization. Disabilities and Culture, Paris: Francon Publishers

UNERPWD.(2006). United Nations Educational Research of People With Disabilities .Education empowering, New York :State Press.

Woolfson, L., Grant, E., Campbell, L. (2007). A Comparison of Special, General and Support Teachers' Controllability and Stability Attributions for Children's Difficulties in Learning. Educational Psychology, 27(2), 295-306. 